\title{
HUBUNGAN STATUS PERNIKAHAN DAN KEPEMILIKAN KONDOM DENGAN PENGGUNAAN KONDOM SAAT MELAKUKAN HUBUNGAN SEKSUAL PADA PASANGAN TIDAK TETAP PENGGUNA NAPZA SUNTIK
}

\author{
Sugiarto \\ Program Studi Kesehatan Masyarakat, STIKES Harapan Ibu Jambi \\ Email: mas_sugik32@yahoo.com
}

\begin{abstract}
ABSTRAK
Konsistensi penggunaan kondom pada Penasun masih rendah. Menurut Laporan STBP 2013, konsistensi penggunaan kondom pada Penasun sebesar $17 \%$ pada pasangan tetap, $17 \%$ pasangan tidak tetap dan $16 \%$ pasangan komersial. Penelitian ini bertujuan untuk melihat hubungan status pernikahan dan kepemilikan kondom dengan penggunaan kondom pada pasangan tidak tetap Penasun di 4 Kota di Indonesia. Penelitian ini menggunakan data sekunder STBP Penasun tahun 2013. Cara pengambilan sampel STBP Penasun adalah Responden Driven Sampling (RDS). Analisis data secara univariat dan bivariat. Hasil penelitian menunjukkan proporsi penggunaan kondom pada saat berhubungan seks dengan pasangan tidak tetap sebesar $17 \%$. Hasil analisis bivariat menunjukkan ada hubungan yang bermakna antara status pernikahan (OR=0,2; 95\% $\mathrm{CI}=0,1-0,6)$, kepemilikan kondom $(\mathrm{OR}=6,6 ; 95 \% \mathrm{CI}=2,4-18,2)$ dengan penggunaan kondom pada pasangan tidak tetap penasun di 4 Kota di Indonesia. Dari hasil penelitian dapat disimpulkan bahwa kepemilikan kondom merupakan faktor risiko penggunaan kondom pada pasangan tidak tetap pengguna napza suntik. Penasun yang tidak memiliki kondom memiliki peluang 7 kali lebih tinggi tidak menggunakan kondom jika dibandingkan dengan penasun yang memiliki kondom baik di Kota Yogyakarta, Tangerang, Pontianak dan Makasar.
\end{abstract}

Kata Kunci : Penasun, Penggunaan Kondom

\section{ABSTRACT}

Consistency of condom use in IDU is still low. According to STBP Report 2013, consistency of condom usage in IDUs was 17\% in fixed couples, $17 \%$ non-permanent partners and $16 \%$ of commercial partners. This study aims to see the relationship between marital status and condom ownership with the use of condoms in non-permanent partner IDUs in 4 cities in Indonesia. This study uses secondary data STBP Penasun year 2013. How to sample STBP IDU is Respondent Driven Sampling (RDS). Univariate and bivariate data analysis. The results showed the proportion of condom use at the time of sex with a nonpermanent partner of $17 \%$. The result of bivariate analysis showed that there was a significant relationship between marital status $(O R=0,2 ; 95 \% C I=0,1-0,6)$, condom ownership $(O R=6,6 ; 95 \% C I=2,4-18,2)$ with condom use in non-permanent partner in IDU in 4 cities in Indonesia. From the research results can be concluded that condom ownership is a risk factor of condom use in non-permanent partner injecting drug users. IDUs who do not have condoms have a 7 times higher chance of not using condoms when compared to IDUs who have good condoms in Yogyakarta, Tangerang, Pontianak and Makassar.

Keywords: IDU, Condom Use

\section{PENDAHULUAN}

Hingga saat ini penyalahgunaan narkoba merupakan salah satu permasalahan kesehatan masyarakat di dunia. Laporan perkembangan situasi narkoba dunia tahun 2014 menunjukkan estimasi pengguna narkoba pada tahun 2010 diantara 3,55,7\%, sedangkan pada tahun 2012 sebesar 3,5\%$7 \%$. Prevalensi penyalahgunaan narkoba di Indonesia pada tahun 2008 dilaporkan sebesar 1,99\%, tahun 2011 sebesar 2,23\%, tahun 2014 sebesar 2,18\% dan pada tahun 2015 sebesar 2,20\%. Salah satu penggunaan narkoba yaitu dengan cara disuntik. Pengguna narkoba suntik pada tahun 2008 diperkirakan berjumlah 1.134 .358 orang, tahun
2014 sebesar 875.248 orang dan pada tahun 2015 sebesar 918.256 orang (BNN, 2015).

Besarnya masalah penyalahgunaan narkoba suntik tidak hanya dari kasusnya yang meningkat, tetapi juga dampak yang ditimbulkan, mencakup fisik, psikologis dan sosial. Secara fisik penggunaan narkoba suntik berpotensi untuk tertular virus hepatitis $\mathrm{B}, \mathrm{C}$ dan HIV/AIDS (Martono, 2006).

Penyebaran HIV saat ini masih terkonsentrasi pada populasi kunci dimana penularan terjadi melalui perilaku yang berisiko seperti penggunaan jarum suntik yang tidak steril pada kelompok pengguna narkoba suntik (penasun), perilaku seks 
yang tidak aman baik pada hubungan heteroseksual maupun homoseksual (KPAN, 2009). Penasun bukan saja memiliki risiko tinggi terinfeksi karena perilaku berbagi jarum suntiknya, tetapi juga memiliki risiko akibat hubungan seksual berganti pasangan dan tidak menggunakan kondom (Widya, 2015).

Pasangan seks yang dimiliki oleh penasun tidak hanya satu orang tetapi lebih dari satu orang. Hasil survey Rapid Assesmend and Response (RAR) (2000) dan BKKBN (2004), menunjukkan bahwa persentase penasun yang memiliki pasangan seks lebih dari satu orang masing-masing sebesar $35-85 \%$ dan 40\% (Irwanto, 2001; BKKBN, 2004). Penasun melakukan hubungan seks setelah menggunakan narkoba sebesar 40\% (Irwanto, 2001).

Mengingat perilaku seksual berisiko yang dimiliki oleh penasun, penggunaan kondom secara konsisten pada kelompok ini sangatlah penting untuk mencegah terjadinya penularan HIV/AIDS pada pasangan mereka baik pasangan tetap maupaun pasangan tidak tetap. Kondom yang digunakan secara tepat dan konsisten terbukti dapat menurunkan risiko penularan HIV/AIDS dengan tingkat efektifitas sebesar 94\% (Weller \& Davis, 2009).

Menurut laporan BKKBN (2004), menyebutkan bahwa IDU mengaku tidak pernah menggunakan kondom bila berhubungan seks dengan pasangan tetap $(59,7 \%)$, dengan teman $(61,9 \%)$, dengan pekerja seks $(44 \%)$, dengan klien (80\%). Hasil STBP (2013), menunjukkan bahwa dari $24 \%$ Penasun yang memiliki pasangan tidak tetap di 2013, 44\% dilaporkan menggunakan kondom pada seks terakhir, $17 \%$ menggunakan kondom pada seks sebulan terakhir dan 16\% menggunakan kondom pada seks setahun terakhir (Kemenkes RI, 2014).

Konsistensi penggunaan kondom ketika berhubungan seks pada penasun sangat rendah. Beberapa penelitian menunjukkan konsistensi menggunakan kondom berkisar antara 5-25\% tergantung pasangannya. Umumnya bila berhubungan dengan pasangan tetap, maka cenderung tidak menggunakan kondom. Sedangkan bila berhubungan dengan pasangan tidak tetap atau dengan PSK menggunakan kondom (Montgomery, Susanne, 2002).

Ada beberapa hambatan yang dapat diidentifikasi misalnya adanya keluhan subjektif pemakai seperti tidak enak, repot atau malu membeli, juga karena citra kondom di masyarakat yang buruk akibat mitos, rumor dan sebagainya. Masyarakat sering mengasosiasikan kondom dengan sesuatu yang kotor, memalukan, terlarang, seks maniak, ketidakjujuran dan perilaku tidak bermoral. Kondom bisa dituduh bisa mendorong peningkatan perilaku zina dan perilaku seksual berisiko lainnya. Norma sosial dan budaya bisa gender juga mempengaruhi orang untuk tidak memakai kondom. Kekuasaan laki-lakilah yang menentukan penggunaan kondom atau tidak (Aulia, 2002).

Penasun menggunakan atau tidak menggunakan kondom saat berhubungan seks dikarenakan beberapa alasan. Alasan menggunakan kondom pada penasun adalah untuk mencegah HIV/IMS. Untuk pasangan tetap dan tidak tetap proporsi cukup besar menyatakan bahwa mereka menggunakan kondom untuk mencegah kehamilan. Sedangkan alasan tidak menggunakan kondom terlihat berbeda pada tiap tipe pasangan. Pada pasangan tetap, proporsi terbesar alasan tidak menggunakan kondom adalah saling mencintai dan percaya, sedangkan pada pasangan tidak tetap dan komersial, proporsi terbesarnya adalah pada alasan ketidaknyamanan menggunakan kondom. Pengenalan akan pasangan dinilai juga cukup dipertimbangkan untuk tidak menggunakan kondom (Tambunan, et al, 2010).

Hasil penelitian yang dilakukan oleh Winahyu, dkk (2016), menunjukkan bahwa perilaku seksual berisiko dipengaruhi oleh status pernikahan, ketersediaan transaksi seksual, keterjangkauan transaksi seksual, keterjangkauan memperoleh kondom dan dukungan rekan kerja.

Berdasarkan hal tersebut, maka perlu diwaspadai bahwa penasun memiliki risiko ganda untuk menularkan HIV selain melalui alat suntik yang tidak steril tetapi juga melalui perilaku seksual yang tidak aman. Patut dijadikan bahan pertimbangan terdapat dua cara penularan HIV pada Penasun, yaitu 1) di dalam kelompoknya sendiri, yaitu melalui perilaku penyuntikan berkelompok, penggunaan alat suntik bekas dan berhubungan seks dengan sesama penasun dan 2) ke masyarakat umum, yaitu melalui hubungan seksual berisiko dengan WPS $^{8}$ (Zani, 2004). Hal tersebut berpotensi pada penyebaran HIV dari Penasun kemasyarakat umum.

\section{METODE}

Penelitian ini merupakan studi kuantitatif dengan menggunakan data sekunder Survei Terpadu Biologi dan Perilaku (STBP) tahun 2013. Survei tersebut dirancang dengan menggunakan desain studi potong lintang. Penelitian ini mengambil sampel yang sudah dilakukan oleh SBTB 2013 yang bertempat tinggal di 4 kota yang menjadi lokasi SBTP Penasun 2013 yaitu Kota Tangerang, Kota Yogyakarta, Kota Pontianak dan Kota Makassar. Adapun kriteria inklusi dalam penasun yang menyuntik dan melakukan hubungan 
seksual dalam satu tahun terakhir. Kriteria eklusi adalah penasun yang tidak pernah melakukan hubungan seksual dalam satu tahun terakhir. Penelitian ini bertujuan untuk melihat perilaku penggunaan kondom pada pengguna napza suntik di 4 Kota di Indonesia. Khusus untuk kelompok sasaran penasun responden berasal dari 4 kota yang tersebar di 4 provinsi. Rancangan sampel yang digunakan pada kelompok penasun STBP 2013 adalah Responden Driven Sampling (RDS) yaitu sebuah teknik sampling secara bola salju (snowball) berdasarkan pada kuota perekrutan (yang menghindari perekrutan keseluruhan sampel dari sejumlah individu terbatas) dan intensif rangkap untuk memotivasi perekrut dan yang direkrut. RDS berawal dari sejumlah kecil peserta yang dipilih secara purposif yang biasanya disebut seed.

\section{HASIL DAN PEMBAHASAN}

Analis is Univariat

\section{Status Pernikahan}

Tabel 1 Distribusi Frekuensi Status Pernikahan Responden

\begin{tabular}{lll}
\hline Status Pernikahan & $\mathrm{n}$ & $\%$ \\
\hline Menikah & 52 & 28,3 \\
Tidak Menikah & 132 & 71,7 \\
Jumlah & 184 & 100,0 \\
\hline
\end{tabular}

Tabel 1. menunjukkan bahwa responden yang menikah sebanyak 52 orang $(28,3 \%)$, sedangkan

responden yang tidak menikah sebanyak 132 orang

\section{Kepemilikan Kondom}

$(71,7 \%)$.

Tabel 2. Distribusi Frekuensi Kepemilikan Kondom Responden

\begin{tabular}{lll}
\hline Kepemilikan Kondom & $\mathrm{N}$ & $\%$ \\
Memiliki & 70 & 38,0 \\
Tidak memiliki & 112 & 60,9 \\
Tidak menjawab & 2 & 1,1 \\
Jumlah & 184 & 100,0 \\
\hline
\end{tabular}

Tabel 2. menunjukkan bahwa responden yang memiliki kondom sebanyak 70 orang $(38,0 \%)$ sedangkan yang tidak memiliki kondom sebanyak 112 orang $(60,9 \%)$

\section{Penggunaan Kondom}

Tabel 3. Distribusi Frekuensi Penggunaan Kondom

\begin{tabular}{lll}
\hline Penggunaan Kondom & $\mathrm{N}$ & $\%$ \\
\hline Selalu & 32 & 17,4 \\
Sering & 64 & 34,8 \\
Tidak Pernah & 88 & 47,8 \\
Jumlah & 184 & 100,0 \\
\hline
\end{tabular}

Tabel 3. menunjukkan bahwa responden yang sering menggunakan kondom sebanyak 64 orang selalu menggunakan kondom saat melakukan (34,8\%) dan yang tidak pernah menggunakan hubungan seksual sebanyak 32 orang $(17,4 \%)$, yang $\quad$ kondom sebanyak 88 orang $(47,8 \%)$.

\section{Analisis Bivariat}

Hubungan Status Pernikahan dengan Penggunaan

Kondom Pada Pengguna Napza Suntik saat

Melakukan Hubungan Seksual

Tabel 4. Hubungan Status Pernikahan dengan Penggunaan Kondom Pada Pengguna Napza Suntik saat Melakukan Hubungan Seksual

\begin{tabular}{lllllll}
\hline \multirow{2}{*}{ Status Pernikahan } & \multicolumn{3}{l}{ Penggunaan Kondom } & \multicolumn{2}{l}{} \\
\cline { 2 - 6 } & Selalu (\%) & Sering (\%) & $\begin{array}{l}\text { Tidak } \\
(\%)\end{array}$ & Pernah & $\mathrm{n}$ & OR \\
\hline Menikah & 9,6 & 32,7 & 57,7 & 52 & 0,2 \\
Tidak Menikah & 20,5 & 35,6 & 43,9 & 132 & \\
\hline
\end{tabular}


Tabel 4. menunjukkan bahwa responden yang menikah dan melakukan hubungan seks dengan pasangan tidak tetap serta selalu menggunakan kondom sebesar 9,6\%, sering menggunakan kondon sebesar $32,7 \%$ dan tidak pernah menggunakan kondom sebesar $57,7 \%$. Sedangkan responden yang tidak menikah dan melakukan hubungan seks dengan pasangan tidak tetap serta selalu menggunakan kondom sebesar 20,5\%, sering menggunakan kondom 35,6\% dan tidak pernah menggunakan kondom sebesar $43,9 \%$.

Hasil penelitian menunjukkan bahwa ada asosiasi antara status pernikahan dengan penggunaan kondom pada pasangan tidak tetap penasun. Penasun yang tidak menikah memiliki kecenderungan 0,2 kali lebih rendah tidak menggunakan kondom pada hubungan seksual dengan pasangan tidak tetap sebulan terakhir jika dibandingkan dengan penasun yang sudah menikah.

Hasil penelitian Silawati (2010), menunjukkan bahwa responden yang belum menikah memiliki kecenderungan 0,7 kali lebih rendah tidak menggunakan kondom jika dibandingkan dengan responden yang sudah menikah.

Status perkawinan diduga memiliki peranan seksual seseorang laki-laki yang sudah menikah diperkirakan memiliki kegiatan seksual berbeda dengan laki-laki yang belum menikah. Logikanya laki-laki yang sudah menikah akan berperilaku sehat dan bertanggungjawab dalam melakukan hubungan seksual dengan pasangannya karena tidak menginginkan dampak negatif dari hubungan seks tersebut. Secara teoritis seseorang yang berstatus belum/tidak menikah mempunyai tingkat perilaku seks yang lebih berisiko, karena untuk melampiaskan hasrat seksualnya mereka cenderung untuk mengakses pekerja seks komersial.

\section{Hubungan Seksual Hubungan Kepemilikan Kondom dengan Penggunaan Kondom Pada Pengguna Napza Suntik saat Melakukan}

Tabel 5. Hubungan Kepemilikan Kondom dengan Penggunaan Kondom Pada Pengguna Napza Suntik saat Melakukan Hubungan Seksual

\begin{tabular}{llllll}
\hline \multirow{2}{*}{ Kepemilikan Kondom } & \multicolumn{3}{l}{ Penggunaan Kondom } & & \\
\cline { 2 - 6 } & Selalu (\%) & Sering (\%) & Tidak Pernah (\%) & $\mathrm{n}$ & OR \\
\hline Memiliki & 27,1 & 47,1 & 25,7 & 70 & 6,6 \\
Tidak Memiliki & 11,6 & 26,6 & 61,6 & 112 & \\
\hline
\end{tabular}

Tabel diatas menunjukkan bahwa responden yang memiliki kondom dan melakukan hubungan seks dengan pasangan tidak tetap serta selalu menggunakan kondom sebesar $27,1 \%$, sering menggunakan kondon sebesar $47,1 \%$ dan tidak pernah menggunakan kondom sebesar $25,7 \%$. Sedangkan responden yang tidak memiliki kondom dan melakukan hubungan seks dengan pasangan tidak tetap serta selalu menggunakan kondom sebesar 11,6\%, sering menggunakan kondom $26,6 \%$ dan tidak pernah menggunakan kondom sebesar $61,6 \%$.

Kecenderungan seseorang untuk menggunakan sesuatu akan didorong oleh ketersediaan sarana prasana. Dalam konteks pencegahan HIV pada penasun, ketersediaan kondom sangat penting. Penasun yang tidak memiliki kondom mempunyai peluang lebih tinggi tidak menggunakan kondom saat melakukan hubungan seks sebulan terakhir jika dibandingkan dengan penasun yang memiliki kondom.

Berbagai alasan yang muncul untuk tidak memiliki kondom atau menggunakan kondom yaitu merasa tidak nikmat untuk melakukan hubungan seks dengan, pasangan tidak tetap karena kondom licin dan dingin. Selain itu, mereka tidak perlu menggunakan kondom sebagai pelindung karena mereka sudah kenal dengan pasangan seksnya. Hasil penelitian Basuki, et al (2002), pelanggan tidak menggunakan kondom karena mereka sudah kenal dengan wanita pekerja seks yang menjadi langanannya. Pelanggan menganggap bahwa berhubungan seks dengan wanita pekerja seks seperti mereka saat berhubungan seks dengan istrinya, sehingga tidak membutuhkan kondom.

\section{SIMPULAN}

Status pernikahan dan kepemilikan kondom berhubungan dengan penggunaan kondom saat melakukan hubungan seksual pada pasangan tidak tetap penasun.

\section{DAFTAR PUSTAKA}

Badan Narkotika Nasional, (2015). Profil Laporan Badan Narkotika Nasional Tahun 2015. Jakarta

Depkes, RI, (2007). Survei Terpadu Biologis Perilaku Pada Kelompok Berisiko Tinggi, 2007 (STBP). Jakarta

Kemenkes. RI, (2014). Laporan Hasil Survei Terpadu Biologis dan Perilaku tahun 2013. Jakarta: Dirjen P2PL 
KPAN, (2009). Analisis Situasi HIV\&AIDS di Indonesia. Outline KPA on ICAAP9. Jakarta

Martono, L Harlina, Satya Joewana, (2006). Modul Latihan Pemulihan Pecandu Narkoba Berbasis Masyarakat. Jakarta: Balai Pustaka.

Silawati, Vivi, (2010). Faktor-Faktor yang Berhubungan dengan Penggunaan Komdom Pada Gay Di Jakarta Tahun 2010. Thesis. FKM UI. Depok

Tambunan, Kamil, Prapthoraharjo, Erlan, \& Irwanto, (2010). Jaringan Seksual dan Penggunaan Napza pada Pengguna Napza Suntik di 6 Propinsi. Unika Atma Jaya: Lembaga Penelitian dan Pengabdian kepada Masyarakat.

Zani, Andri Y, Prima, (2004). Potensi Penyebaran HIV dari Pengguna Napza Suntik ke Masyarakat Umum di Jakarta. Thesis. Depok: FKM UI. 